DOI: 10.46340/eujem.2020.6.4.6

Dmytro Maslov

ORCID ID: https://orcid.org/0000-0002-1721-8319

Odesa National Economic University, Ukraine

\title{
INEQUALITY AND PUBLIC DEBT \\ FROM THE PERSPECTIVE \\ OF THE REPRODUCTIVE APPROACH
}

\author{
Дмитро Маслов \\ Одеський національний економічний університет, Україна

\section{ЕКОНОМІЧНА НЕРІВНІСТЬ ТА ДЕРЖАВНИЙ БОРГ З ТОЧКИ ЗОРУ ВІДТВОРЮВАЛЬНОГО ПІДХОДУ}

The paper suggests considering the relationship between public debt and inequality in terms of a reproductive approach. It is shown that there is an objective need for public debt growth due to the existence of a contradiction of the reproduction of social capital - between the volume and structure of demand and the volume and structure of supply. Prerequisites for public debt growth and inequality are formed due to the contradictions of the reproduction of social capital. After endowing the state with socio-economic functions, public debt became an important mechanism for the transfer of capital outside the existing structure of demand. Public debt arises from the need to balance the proportions of reproduction of public capital to ensure the sale of relatively excess mass of commodities. From the point of view of the reproductive approach, the debt looks like a loan from the creditor-producer to the borrower-buyer for the sale of the creditor's commodities.

Keywords: public debt, inequality, reproduction, social capital, expanded reproduction, capital accumulation, public expenditures, debt, commodities.

Постановка проблеми. Державний борг звичайно розглядається як наслідок бюджетного дефіциту, вибору уряду витрачати більше, ніж існує державних доходів від оподаткування, штрафів та ін. Сама наявність державного боргу розглядається як фактор зростання економічної нерівності у суспільстві. 3 цими поглядами можна погодитися, але вони не охоплюють більш глибокі проблеми, що пов'язані з державним боргом. Такою є проблема об'єктивної необхідності державного боргу через існування суперечності відтворення суспільного капіталу - між об'ємом і структурою попиту та об’ємом і структурою пропозиції. Через державний борг зростає економічна нерівність, у той же час через економічну нерівність зростає державний борг, але передумови для зростання і державного боргу і економічної нерівності є глибші та формуються через суперечності відтворення суспільного капіталу.

Аналіз останніх джерел та публікацій. Проблеми відтворення суспільного капіталу досліджувалися представниками класичної політичної економії та їх критиками, ставилися питання про можливість надмірності капіталу, невідповідності об'єму і структури попиту та об'єму і структури пропозиції. Представники кейнсіанського напряму доповнили аналізі врахуванням ролі держави у впливі на економічні процеси. Зв'язок державного боргу та економічної нерівності розглядався у роботах Б. Мілановіча, Дж. Стігліца, Т. Пікетті та ін. У той же час проблема державного боргу та нерівності досліджувалася у відриві від відтворення суспільного капіталу, що дозволяло розглядати проблему лише на поверхневому рівні.

Мета даної статті - здійснити більш глибокий погляд на проблему державного боргу та економічної нерівності через теорію відтворення суспільного капіталу.

Виклад основного матеріалу. Представники класичної політичної економії вважали, що капітал не може бути надмірним, не має внутрішніх обмежень для власного зростання. 
Першим про обмеженість можливостей нагромадження капіталу говорив Джеймс Мейтленд, 8й граф Лодердейл. Він пов'язує скорочення попиту та споживчі товари із скороченням попиту на капітал, тобто попит на споживчі товари встановлює обмеження на зростання капіталу.

Граф Лодердейл критикує А. Сміта та фізіократів, які вважали, що заощадження є благом та умовою нагромадження капіталуㄹ․ Лодердейл, навпаки, вважає заощадження, по відношенню до усієї національної економіки, злом. Говорячи про примусові заощадження, які планував здійснювати британський уряд для погашення державного боргу, він відмічає: «Все, що ми стверджували, і все, що ми прагнули довести, зводиться до того, по-перше, що старе правило «збережений пенс - це зароблений пенс» не застосовується до суспільного багатства» ${ }^{3}$. Більше того, Лодердейл вказує, що при скороченні попиту величина, на яку скоротиться виробництво, буде набагато більшою за величину скорочення попиту ${ }^{4}$, що знаходиться у відповідності до концепції мультиплікатора, чітко сформульованої пізніше.

Т. Мальтус також брав участь у полеміці з представниками класичної політичної економії, зокрема з Д. Рікардо, захищаючи точку зору, що перенагромадження капіталу та загальне переповнення ринку товарами можливе. Надмірне нагромадження капіталу відносно ефективного попиту спричиняє зниження норми прибутку. Якщо б суспільство «скоротило своє споживання» i, за рахунок збільшення заощаджень, «збільшило б додатково свій капітал, то не може бути ні найменшого сумніву, якщо мати на увазі принцип попиту і пропозиції, що прибутки капіталістів були б незабаром значно зменшені, хоча б не було поганих земель в обробці; і населення залишилось без роботи і голодувало б, не дивлячись на те, що не було введено жодного податку чи будь-якого обмеження на торгівлю» 5 .

Для підтримання «ефективного попиту» Т. Мальтус вважав необхідним існування «непродуктивних споживачів», які не були зайняті у секторі матеріального виробництва ${ }^{6}$.

Подальшого розвитку проблема неспівпадіння об'єму і структури пропозиції з об'ємом і структурою попиту набула у працях С. Сісмонді. Характеризуючи систему пропорцій відтворення суспільного капіталу в цілому, С. Сісмонді вказував на внутрішньо притаманну їй диспропорційність.

Значний внесок С. Сісмонді в теорію відтворення суспільного капіталу полягає в тому, що він розглядає не відтворення взагалі, не абстрактний зв'язок між виробництвом взагалі і споживанням взагалі, не відтворення індивідуального капіталу, але систему пропорцій відтворення суспільного капіталу. С. Сісмонді наполягає на тому, що пропорції відтворення безпосередньо пов'язані між собою, і це повинно обов'язково враховуватися під час дослідження. Багатство суспільства зростає тільки тоді, коли частини системи відтворення - дохід та каптал - зростають пропорційно і знаходяться у відповідності одна до одної .

С. Сісмонді критично ставиться до праць економістів класичної політичної економії, які вважали кризи перевиробництва неможливими. Давид Рікардо, підтримуючи погляди Жана-Батіста Сея на проблему співвідношення суспільного попиту і виробництва (пропозиції), стверджує, що попит обмежується лише виробництвом ${ }^{8}$. С. Сісмонді зазначає, що головна помилка економістів полягає в змішуванні річного виробництва і річного доходу. Хоча доходи безпосередньо пов'язані 3 виробництвом, але оскільки не одна частина річного виробництва купує іншу частину річного виробництва, а річне виробництво купується на доходи, остільки можлива розбіжність обсягу і структури виробництва та обсягу і структури доходів ${ }^{9}$; або розбіжність обсягу і структури пропозиції та обсягу і структури попиту.

\footnotetext{
${ }^{1}$ Lauderdale, J. M. (1819). Inquiry into the nature and origin of public wealth. (2nd ed.). Edinburgh: Longman, Hurst, Rees, Orme, and Brown, And Hurst, Robinson, And Company, 262-263.

2 Тюрго, Ж. (2008). Размыиления о создании и распределении богатств. Москва: Эксмо, 623.

${ }^{3}$ Lauderdale, J. M. (1819). Inquiry into the nature and origin of public wealth. (2nd ed.). Edinburgh: Longman, Hurst, Rees, Orme, and Brown, And Hurst, Robinson, And Company, 263-265.

4 Tам само, 246.

${ }^{5}$ Malthus, T. R. (1836). Principles of political economy. London: W. Pickering, 277-278.

6 Там само, 266.

${ }^{7}$ Сисмонди, С. Ж. (1937). Новые начала политической экономии, или О богатстве в его отношении к народонаселению. Москва: Государственное социально-экономическое издательство, 1, 197.

${ }^{8}$ Сисмонди, С. Ж. (1937). Новые начала политической экономии, или О богатстве в его отнотении к народонаселению. Москва: Государственное социально-экономическое издательство, 2, 239.

${ }^{9}$ Сисмонди, С. Ж. (1937). Новые начала политической экономии, или О богатстве в его отномении к народонаселению. Москва: Государственное социально-экономическое издательство, 1, 317.
} 
Змішення виробництва і доходів, пропозиції і попиту відбувається через надмірно абстрактний розгляд суспільного виробництва. Такий розгляд відволікається від розриву в часі і просторі актів купівлі та продажу, від грошей, що функціонують як засіб накопичення і платежу, від обсягу і структури пропозиції - які саме товари продаються, від обсягу і структури попиту - хто із суб'єктів попиту які товари купує і на які доходи. Без урахування даних обставин неможливо пояснити періодичне переповнення ринків, неможливо пояснити «як можуть падати прибуток на капітал і заробітна плата, в той час як виробництво зростає» 1 .

К. Маркс розвиває погляди С. Сісмонді на відтворення суспільного капіталу як на співвідношення різних частин суспільного продукту. Він вказує на внутрішні суперечності системи відтворення та особливо відтворення суспільного капіталу у розширеному масштабі, тобто процесу нагромадження. К. Маркс стверджує, що умови виробництва суспільного продукту та його реалізації не $\epsilon$ тотожними. Якщо умови виробництва обмежені лише продуктивною силою суспільства, то умови реалізації залежать від пропорційності різних галузей виробництва та споживної сили суспільства. Але ці умови визначаються «не абсолютною продуктивною силою і не абсолютною споживною здатністю, але споживною здатністю на основі антагоністичних відносин розподілу, які зводять споживання величезної маси суспільства до мінімуму, що змінюються лише в більш-менш вузьких межах» ${ }^{2}$. Споживна здатність суспільства, окрім цього, обмежена прагненням до нагромадження капіталу, чим більша частина прибутку використовується для збільшення капіталу, тим менша частина залишається для використання у якості засобу купівлі товарів індивідуального споживання. Таким чином, з огляду на необхідність реалізації товарів, які стають «зайвими», ринок для цих товарів повинен «постійно розширюватися, звідси взаємозалежність ринкових відносин іiі умов, що іiі визначають, все більше приймають характер незалежного від виробників природного закону і все менше піддаються контролю. Внутрішня суперечність прагне знайти собі вирішення в розширенні зовнішнього поля виробництва. Але чим більше розвивається продуктивна сила, тим більше впадає вона в суперечність з тим вузьким базисом, на якому спочиває споживання. На цій основі, повної суперечностей, аж ніяк не суперечність те явище, що надлишок капіталу пов'язаний із зростаючим надлишком населення».

М. Туган-Барановський при дослідженні «проблеми ринку», або, конкретніше, співвідношення об’єму і структури пропозиції з об'ємом і структурою попиту у суспільстві спирався на модель відтворення суспільного капіталу, сформульовану К. Марксом. М. Туган-Барановський виступає 3 критикою поглядів на «проблему ринку» Т. Мальтуса, С. Сісмонді, К. Маркса, стверджуючи, що вони мали невірне розуміння процесу товарного обігу у капіталістичному господарстві ${ }^{3}$. Суть критики полягала у тому, що вони розглядали ринок лише як споживчий попит. Тобто товари на ринку купуються лише для особистого споживання при використанні доходів різних класів суспільства. Насправді, каже М. Туган-Барановський, «капітал, що нагромаджується, перетворюється не тільки в заробітну плату, а й в засоби виробництва, що не становлять елемента споживання якого 6 то не було класу населення» ${ }^{4}$. Далі він переходить до розв'язання «проблеми ринків» ${ }^{5}$, як наче це не реальна проблема економічної дійсності, а лише теоретична проблема, що виникла через недостатній науковий хист його попередників в дослідженні даного питання. Тому він береться вирішувати дану теоретичну проблему, так і назвавши 4 главу своєї книги: «Вирішення проблеми ринків». Але «проблема ринків»- це не проблема лише теорії, це проблема ринків, і ринкам іiі вирішувати. Це реальна суперечність, яка провокує появу нових явищ, призводить економіку до нового етапу їі розвитку.

Для розв'язання «проблеми ринків» М. Туган-Барановський використовує модель відтворення суспільного капіталу, побудовану К. Марксом. В цій моделі К. Маркс продемонстрував, що, за прийнятих передумов, просте та розширене відтворення у капіталістичній економіці можливе. Як і будь-яка модель, вона є ілюстрацією проблеми на визначеному рівні абстракції, що обмежується певними передумовами. Однією з цих передумов є відсутність циклічності в ході відтворення суспільного капіталу: в моделі К. Маркса нагромадження капіталу відбувається поступово,

\footnotetext{
1 Там само.

${ }^{2}$ Маркс, К., Энгельс, Ф. (1961). Капитал. Москва: Политиздат, 3, 286.

3 Туган-Барановский, М. И. (2008). Избранное. Периодические промышленные кризисы. История английских кризисов. Москва: Директмедиа Паблишинг, 241.

4 Там само, 249.

${ }^{5}$ Там само, 250.
} 
суспільний продукт зростає на $10 \%$ щорічно, без жодних коливань, ніхто з суб’єктів процесу відтворення не здійснює жодних заощаджень, об'єм та структура пропозиції повністю збігається з об'ємом та структурою попиту. М. Туган-Барановський використовує цю модель для того, щоб довести відсутність «проблеми ринку». I це йому вдається, тому що відсутність «проблеми ринку» закладена у передумови прийнятого рівня абстракції для даної моделі: «Наведені схеми повинні були з очевидністю довести думку, яка сама по собі дуже проста, але легко викликає заперечення при недостатньому розумінні процесу відтворення суспільного капіталу, а саме, що капіталістичне виробництво саме для себе створює ринок. Якщо тільки можна розширити виробництво, якщо вистачить для цього продуктивних сил, то при пропорційному розподілі суспільного виробництва, можна відповідно розширити і попит, бо за цієї умови кожен знову вироблений товар є купівельна сила, яка знову з'являється для придбання інших товарів» ${ }^{1}$. Таким чином, М. Туган-Барановський приходить до того ж висновку, що і Ж.-Б. Сей.

М. Туган-Барановський доповнює модель відтворення суспільного капіталу через включення у неї проявів технічного прогресу. Він розглядає технічний прогрес як працезберігаючий: машини витісняють з виробництва робочу силу, та це не створює проблеми реалізації суспільного продукту, оскільки при скороченні попиту на предмети особистого споживання відповідно зростає попит на засоби виробництва - один вид попиту заміняє іншийㄹ. Але технічний прогрес передбачає не лише заміщення людей машинами, але $\mathrm{i}$ зростання продуктивності праці. Технічні інновації впроваджуються для скорочення витрат на одиницю продукції та для зростання продуктивності виробництва. Технічні інновації впроваджуються не в абстрактному виробництві «взагалі», а на конкретних підприємствах. Якщо підприємства виробляють засоби виробництва, то зростання продуктивності на цих підприємствах збільшує кількість засобів виробництва, що є продуктом даних підприємств. Якщо продуктивність зростає на підприємствах, що вироблять предмети особистого споживання, то відповідно збільшується кількість предметів особистого споживання. Впровадження інновацій створює попит для нових засобів виробництва, але для нових предметів особистого споживання попит не створюється. Він, навпаки, зменшується, якщо робоча сила вибуває з виробництва. У такому випадку нема кому купувати нові предмети особистого споживання. Ця проблема залишається навіть при розгляді зростання продуктивності за відсутності витіснення робочої сили машинами, якщо темп зростання реальної зарплати робочої сили відстає від темпу зростання продуктивності ${ }^{3}$.

М. Туган-Барановський описує механізм розширення основного капіталу як такий, що відбувається «поштовхами», коли нагромадження «вільного позичкового капіталу» досягає міри, тобто такого масштабу, «що опір промисловості долається, капітал проникає в промисловість і знаходить собі застосування. Настає епоха промислового підйому» ${ }^{4}$. Вільний позичковий капітал являє собою «купівельну силу, що знаходиться у спокої», та коли він застосовується у якості промислового капіталу, витрачається на купівлю засобів виробництва та робочої сили, промисловість «раптово відкриває новий ринок», створюється новий попит 5 . Таким чином, М. Туган-Барановський тут доходить того ж висновку, з яким сперечався в особі С. Сісмонді, Т. Мальтуса та К. Маркса. Новий попит створює можливості для розширення виробництва: «Для промисловості байдуже, на чому грунтується раптове збільшення попиту. Для неї важливо лише те, що попит дійсно збільшився на всю суму капіталу, що був нагромаджений і нині витрачається. Товарні ціни підвищуються, і виробництво розширюється по всій лінії» ${ }^{6}$. Коли вільний позичковий капітал закінчується, відбувається промислова криза ${ }^{7}$. Швидке розширення основного капіталу завершується, попит скорочується на матеріали, з яких виробляється основний капітал, але перетворити основний капітал знову

\footnotetext{
${ }^{1}$ Туган-Барановский, М. И. (2008). Избранное. Периодические промышиенные кризисы. История английских кризисов. Москва: Директмедиа Паблишинг, 256.

2 Там само, 259.

3 Жданова, Л. Л. (2013). Воспроизводство общественного капитала в условиях технического прогресса. Вопросы политической экономии, 4, 39-53.

${ }^{4}$ Туган-Барановский, М. И. (2008). Избранное. Периодические промышленные кризисы. История английских кризисов. Москва: Директмедиа Паблишинг, 322.

${ }^{5}$ Там само, 323.

${ }^{6}$ Там само.

7 Туган-Барановский, М. И. (2008). Избранное. Периодические промышленные кризисы. История английских кризисов. Москва: Директмедиа Паблишинг, 324.
} 
на позичковий вже не так просто, продати підприємства не вийде, бо скорочується попит, капітал «вимагає продовження виробництва», щоб компенсувати хоч деякі витрати, «перевиробництво засобів виробництва робиться неминучим» ${ }^{2}$. Постає питання, яким чином можна збільшити попит після настання кризи, який міг би поглинути надлишкову пропозицію засобів виробництва та предметів споживання?

В моделі М. Туган-Барановського можлива реалізація надлишкових товарів у інші країни, але якщо вони знаходяться на докапіталістичному рівні розвитку. В той же час, економічна практика демонструє, що реалізація надлишкових товарів можлива не тільки в докапіталістичні країни, але і у інші капіталістичні країни, та ці країни повинні мати від'ємний торговий баланс. Від'ємний торговий баланс може бути компенсований припливом іноземних грошей у якості позик. Навіть якщо ці позики використовуються для наповнення міжнародних резервів країни-імпортера, у кінцевому підсумку результат буде незмінним, адже центральний банк цієї країни використовує резерви для валютних інтервенцій і підтримання валютного курсу. Валюту викуповують приватні імпортери для купівлі товарів на міжнародному ринку. В той же час зміцнення курсу національної валюти закріплює імпортну залежність від іноземних засобів виробництва.

Розглядаючи нагромадження вільного позичкового капіталу, М. Туган-Барановський не помічає проблеми, яка з цим пов'язана. Він вказує, що такий капітал утворюється «з капіталізованої частини доходів самих різних суспільних класів» ${ }^{2}$, де «капіталізація» означає не використання у якості продуктивного капіталу, а заощадження у банку. Але, якщо виходити 3 системного відтворювального підходу до аналізу суспільного виробництва, утворення таких заощаджень означає неможливість реалізації частини товарів виробниками. Ці товари можуть бути реалізовані, якщо заощадження будуть перетворені у позики для потенційних покупців даних товарів, тобто за допомогою створення боргу.

Представники кейнсіанського напряму економічної думки звертали увагу на проблему заощаджень, як фактору, що утруднює реалізацію суспільного продукту та призводить до економічних криз: «надмірний розвиток звички до заощадження... збіднює суспільство, викидає людей на вулицю, скорочує заробітну плату, сіє зневіру і пригніченість в діловому світі, які відомі під ім'ям економічних депресій» ${ }^{3}$. Дж. Кейнс розглядав заощадження як частину доходу, що не витрачається на споживання. Ця частина доходу зростає зі зростанням доходу: «Психологія суспільства $\epsilon$ такою, що зі зростанням сукупного реального доходу збільшується і сукупне споживання, проте не в такій же мірі, в якій росте дохід» ${ }^{4}$. Співвідношення між сукупним доходом і величиною очікуваних витрат на споживання, залежить «від психологічної характеристики суспільства, яку ми будемо називати його схильністю до споживання. Це означає, що споживання буде залежати від рівня сукупного доходу і, отже, від рівня зайнятості, якщо тільки не відбудуться зміни в схильності до споживання» ${ }^{5}$. Саме в цій характеристиці суспільства Кейнс вбачає основну проблему ${ }^{6}$. Дж. Кейнс розглядає схильність до споживання для всього суспільства, яка знижується разом із зростанням зайнятості. Але вона може знижуватися і при відсутності зростання зайнятості, i навіть при падінні зайнятості. Схильність до споживання залежить від розподілу доходів у суспільстві, значна нерівність у розподілі доходів зменшує величину споживання.

Чим більший є капітал, тим швидше він зростає. Заробітна плата, навпаки, зростає повільно. Якщо доходи та багатство однієї частини суспільства (власників капіталу) зростають швидше, ніж доходи іншої частини суспільства, це призводить до зниження схильності до споживання для всього суспільства у порівнянні з ситуацією, коли доходи усього суспільства зростають більш менш однорідно. У першому випадку більша частина доходів і багатства концентрується в руках невеликої частини суспільства, потреби яких у предметах споживання вже є задоволеними. Таким чином, заощадження зростають швидше. Звичайно, ці заощадження можуть перетворюватися у інвестиції, але при скороченні схильності до споживання у суспільстві скорочується сукупний попит та можливості для застосування капіталу у якості інвестицій у реальний сектор. Мультиплікатор

\footnotetext{
1 Там само, 325.

2 Там само, 320.

${ }^{3}$ Кейнс, Дж. М. (2007). Общзая теория занятости, процента и денег. Избранное. Москва: Эксмо, 442.

4 Там само, 80.

5 Там само, 81.

6 Там само, 83.
} 
інвестицій, який прямо залежить від граничної схильності споживання ${ }^{1}$, у таких умовах також буде працювати гірше, тобто буде мати меншу величину. 3 іншого боку, існують можливості для використання даних заощаджень для спекулятивних операцій на ринках фіктивного капіталу, для викупу акцій інших компаній з метою отримання дивідендів та подальшої концентрації та централізації власного капіталу, для викупу акцій власних компаній з метою збільшення величини капіталізації на фондовому ринку, для викупу облігацій державної позики з метою отримання відсотків тощо.

Таким чином, зростання нерівності у суспільстві призводить до зниження схильності до споживання та, відповідно, до скорочення попиту і ускладнень реалізації суспільного продукту. У період з 1986 по 2012 рік заощадження найбагатших 10\% населення США складали 22\% від їхнього доходу, у той час як заощадження решти 90\% населення складали $0 \%$, відповідно схильність до споживання у першої групи дорівнювала 0,78 , а у другої - $100 \%$, що $€$ підтвердженням «основного психологічного закону»².

Дж. Кейнс стверджував, що держава може здійснювати заходи з перерозподілу доходів, що ведуть до збільшення схильності до споживання, що буде сприятливим для зростання капіталу. Такими заходами можуть бути більш високі прогресивні податки, які і були запровадженні після «Великої Депресії» у відповідності до кейнсіанських рекомендацій, та існували упродовж періоду так званої «золотої доби» капіталізму. Але з 1970x років податки почали знижуватися, та перерозподіл не припинився, але він прийняв іншу форму. У цей час активно починає зростати державний борг.

Е. Хансен, як і Дж. Кейнс, розглядає державу як суб'єкта впливу на пропорції відтворення суспільного капіталу. Зокрема, він вказує на те, що державні видатки грали дуже значну роль під час економічної експансії після «Великої депресії» у період 1933-1937 рр., на відміну від експансії 20-х років XX ст., яка визначалася у більшій мірі приватними інвестиціями ${ }^{3}$. Державні видатки також грали визначальну роль під час світових війн.

Інвестиції перетворюють заощадження у попит. Відмінність державних видатків від приватних інвестицій полягає у тому, що інвестиції представляють собою не лише попит на інвестиційні товари, але і створюють пропозицію нових товарів, які є результатом інвестиційної діяльності, і вартість яких повинна бути поглинута ринком. Нові інвестиції не збільшують схильність до споживання у суспільстві, отже не можуть подолати межу, яку ця схильність встановлює для можливостей нагромадження капіталу. Більшу частину державних видатків сьогодні складають «соціальні» видатки: пенсії, допомога безробітнім, людям з інвалідністю, медичні послуги, освіта; та видатки на зарплати державним працівникам - поліції, армії, чиновникам - тобто витрати на придбання предметів споживання. Результатом державних витрат не будуть товари, які мають знайти собі ринок для того, щоб бути реалізованими, державні видатки $\epsilon$ створенням такого ринку для вже вироблених товарів. Те саме справедливо і для державних інвестицій в інфраструктуру: дорога, побудована державним коштом, не потребує реалізації на ринку, але будування дороги потребує інвестиційних та споживчих товарів. Таким чином, в результаті державних видатків збільшується схильність до споживання для усього суспільства, і це збільшує мультиплікативний ефект та розширює можливості капіталу для зростання.

Постає питання про фінансування державних видатків, але це питання вирішується у кожній конкретній історичній ситуації відповідно до балансу економічних сил, що існують у суспільстві. Після кризи «Великої Депресії» більш сильними виявилися представники економічних інтересів робочого класу, тому державні видатки фінансувалися за рахунок високих прогресивних податків. У багатьох країнах світу після кризи та Другої світової війни влада капіталу була обмежена, з цього часу спостерігається злам у тенденції зростання нерівності ${ }^{4}$. Але у 70ті та 80ті роки XX ст. перемагають інтереси саме тих, на кого лягав основний тягар прогресивних податків, тому податки

\footnotetext{
${ }^{1}$ Кейнс, Дж. М. (2007). Общчая теория занятости, процента и денег. Избранное. Москва: Эксмо, 179.

${ }^{2}$ Saez, E., Zucman, G. (2014) Wealth Inequality in The United States Since 1913: Evidence from Capitalized Income

Tax Data. National Bureau of Economic Research. <https:/www.nber.org/papers/w20625.pdf> (2020, Травень, 15).

${ }^{3}$ Хансен, Э. (1959). Экономические цุикль и национальный доход. Москва: Издательство иностранной литературы, 294.

${ }^{4}$ Миланович, Б. (2017). Глобальное неравенство. Новый подход для эпохи глобализации. Москва: Издательство Института Гайдара, 122-123.
} 
починають знижуватися, реальна заробітна плата перестає зростати, зростає нерівність ${ }^{1}$, знижується схильність до споживання, що посилює проблему реалізації суспільного продукту. Фінансування державних видатків більшою мірою фінансується вже за рахунок державного боргу. Т. Пікетті вказує, що більшу частину історії норма дохідності капіталу перевищує темпи зростання економіки ${ }^{2}$. Чим більшою $є$ ця різниця, тим меншою є частина прибутку (ренти, відсотка, дивіденда і т.п.), яка використовується у якості чистих інвестицій, тобто для нагромадження, адже темп зростання економіки і є виразом нагромадження капіталу. Відповідно, більшою є частина прибутку, (ренти, відсотка, дивіденда і т.п.), яка іде або на особисте споживання, або на заощадження, що не перетворюються у інвестиції, а нагромаджуються у якості «вільного позичкового капіталу». Таким чином, вільний позичковий капітал нагромаджується та потребує реалізації, перетворення у інвестиції, але зіштовхується з обмеженням попиту. Через посередництво державного боргу надлишкові заощадження створюють новий попит і одночасно створюють можливість для зростання інвестицій за мультиплікативним ефектом. Тобто відбувається трансфер капіталу за межі існуючої структури попиту в середині країни.

3 іншого боку, розвиток світової торгівлі прискорюється, для розвинутих країн відкривається більше можливостей для реалізації надлишкових інвестиційних та споживчих товарів за кордоном, але менш розвинуті країни мають імпортувати більше товарів, ніж вони експортують, а це можливо лише у випадку, коли менш розвинуті країни позичають гроші. Тут для розвинутих країн відкривається можливість реалізації своїх заощаджень у формі позик менш розвинутим країнам.

Висновки. Відтворювальний підхід дозволяє дати більш глибокий аналіз зв'язку економічної нерівності та державного боргу. Технічний прогрес, який супроводжує розширене відтворення суспільного капіталу, призводить до відносного скорочення зайнятості і зниження вартості робочої сили, що диктується прагненням до підвищення ефективності виробництва, але, в той же час, створює ускладнення для реалізації вироблених товарів. У замкнутій системі відтворення борг виникає з необхідності реалізації суспільного продукту. Якщо в системі пропорцій суспільного відтворення немає доходів для реалізації суспільного продукту, їх можна створити лише за допомогою перерозподілу, яким у бездержавній економічній системі може виступати лише борг. Після наділення держави соціально-економічними функціями державний борг став важливим механізмом трансферу капіталу за межі існуючої структури попиту. Державний борг існує об'єктивно і виникає з потреб балансування пропорцій відтворення суспільного капіталу для забезпечення реалізації відносно надлишкової маси товарів. Незалежно від виду боргових відносин, з точки зору відтворювального підходу, борг виглядає як позика від кредитора-виробника позичальнику-покупцю задля реалізації товарів кредитора.

\section{References:}

1. Lauderdale, J. M. (1819). Inquiry into the nature and origin of public wealth. (2nd ed.). Edinburgh: Longman, Hurst, Rees, Orme, and Brown, And Hurst, Robinson, And Company. [in English].

2. Turgot, J. (2008). Razmyshlenija o sozdanii i raspredelenii bogatstv [Reflections on the Formation and Distribution of Wealth]. Moscow: Eksmo. [in Russian].

3. Malthus, T. R. (1836). Principles of political economy. (2nd ed.). London: W. Pickering. [in English].

4. Sismondi, S. (1937). Novye nachala politicheskoj jekonomii, ili O bogatstve v ego otnoshenii $k$ narodonaseleniju [New Principles of Political Economy: Of Wealth in Its Relation to Population]. Moscow: State Socio-Economic Publishing House, 1. [in Russian].

5. Sismondi, S. (1937). Novye nachala politicheskoj jekonomii, ili O bogatstve v ego otnoshenii k narodonaseleniju [New Principles of Political Economy: Of Wealth in Its Relation to Population]. Moscow: State Socio-Economic Publishing House, 2. [in Russian].

6. Marx, K., Engels, F. (1961). Kapital [Capital]. Moscow: Politizdat, 3. [in Russian].

7. Tuhan-Baranovskyi, M. (2008). Izbrannoe. Periodicheskie promyshlennye krizisy. Istorija anglijskih krizisov [Selected works. Periodic industrial crises. History of English crises]. Moscow: Direktmedia Pablishing. [in Russian].

8. Zhdanova, L. L. (2013). Vosproizvodstvo obshhestvennogo kapitala v uslovijah tehnicheskogo progressa [Reproduction of social capital under conditions of technical progress]. Voprosy politicheskoj jekonomii [Political Economy Issues], 4, 39-53. [in Russian].

\footnotetext{
${ }^{1}$ Миланович, Б. (2017). Глобальное неравенство. Новый подход для эпохи глобализации. Москва: Издательство Института Гайдара, 124-125.

2 Пікетті, Т. (2016). Капітал у XXI столітmі. Київ: Наш Формат, 32.
} 
9. Keynes, J. (2007). Obshhaja teorija zanjatosti, procenta i deneg. Izbrannoe [The General Theory of Employment, Interest and Money. Selected works]. Moscow: Eksmo. [in Russian].

10. Saez, E., Zucman, G. (2014) Wealth Inequality in The United States Since 1913: Evidence from Capitalized Income Tax Data. National Bureau of Economic Research. <https:/www.nber.org/papers/w20625.pdf> (2020, May, 15). [in English].

11. Hansen, A. (1959). Ekonomicheskie tsikly i natsionalnii dokhod [Business cycles and national income]. Moscow: Izdatelstvo inostrannoy literatury. [in Russian].

12. Milanovich, B. (2017). Globalnoe neravenstvo. Novyj podhod dlja jepohi globalizacii [Global inequality: A New Approach for the Age of Globalization]. Moscow: Izdatelstvo Instituta Gajdara. [in Russian].

13. Piketty, T. (2016). Kapital u XXI stolitti [Capital in the Twenty-First Century]. Kyiv: Nash Format. [in Ukrainian]. 